\title{
Ovarian hyperstimulation syndrome and pulmonary edema - a rare complication
}

\section{Vineet Mishra*, Priyankur Roy, Sumesh Choudhary, Rohina Aggarwal, Shaheen Hokabaj, Suwa Ram Saini}

Department of Obstetrics and Gynecology, IKDRC-ITS, Ahmedabad, Gujarat, India

Received: 03 January 2017

Accepted: 03 February 2017

\author{
*Correspondence: \\ Dr. Vineet Mishra, \\ E-mail: vineet.mishra.ikdrc@gmail.com
}

Copyright: (C) the author(s), publisher and licensee Medip Academy. This is an open-access article distributed under the terms of the Creative Commons Attribution Non-Commercial License, which permits unrestricted non-commercial use, distribution, and reproduction in any medium, provided the original work is properly cited.

\begin{abstract}
Background: Ovarian Hyperstimulation Syndrome (OHSS) is a life-threatening complication of controlled ovarian stimulation almost exclusively associated with gonadotropins but occasionally with clomiphene citrate. Prevention of this syndrome lies in the recognition of risk factors and individualizing the treatment regimens. Causes of respiratory distress in patients with OHSS are pleural effusion, pulmonary embolism, and acute respiratory distress syndrome (ARDS). Pulmonary edema is rare but a grave complication of OHSS.

Case report: We report, a case of severe OHSS with tense ascites and anasarca after controlled ovarian hyperstimulation $(\mathrm{COH})$ for IVF. She was managed conservatively followed by paracentesis after which she developed pulmonary edema during the course of the treatment.

Conclusion: OHSS is an iatrogenic complication which can be prevented by individualizing stimulation protocols and should be managed urgently with a multidisciplinary approach
\end{abstract}

Keywords: Gonadotropins, Ovarian hyperstimulation syndrome, Pulmonary edema

\section{INTRODUCTION}

OHSS is an iatrogenic complication which is usually selflimiting but may be life threatening in severe cases. Overstimulation of the ovaries results in marked ovarian enlargement and is manifested by massive ascites, hypovolemia, hemoconcentration, pleural effusion, electrolyte imbalance, oliguria and thromboembolism in severe cases. ${ }^{1}$ The incidence of moderate to severe OHSS has been found to be $0.2 \%$ to $2 \%$ of all ovarian stimulation cycles. ${ }^{2}$

The pathophysiology of OHSS is not completely known but is characterized by increased capillary permeability resulting in a fluid shift from the vascular compartment to the third space leading to extra vascular fluid accumulation and intravascular dehydration.
Accumulation of protein-rich fluid in the peritoneal cavity leads to increased intra-abdominal pressure which may compromise respiratory, cardiovascular, renal, gastrointestinal and hepatic system homeostasis. ${ }^{3}$ Human chorionic gonadotropin (hCG) is the main factor that triggers OHSS by increasing the production of various vasoactive substances including vascular endothelial growth factor (VEGF) resulting in increased vascular permeability. ${ }^{4}$ Pulmonary edema (both low and high pressure) has been reported in patients with OHSS and is attributed to excessive capillary permeability. ${ }^{5}$

\section{CASE REPORT}

A 26-year-old infertile female having body mass index (BMI) of 24 with polycystic ovaries underwent in vitro fertilization (IVF) using long luteal protocol at IKDRC, 
Ahmedabad. Recombinant FSH 225 IU was administered for 10 days for ovarian stimulation after which she developed multiple follicles with enlarged ovaries and fluid in POD (Figure 1).

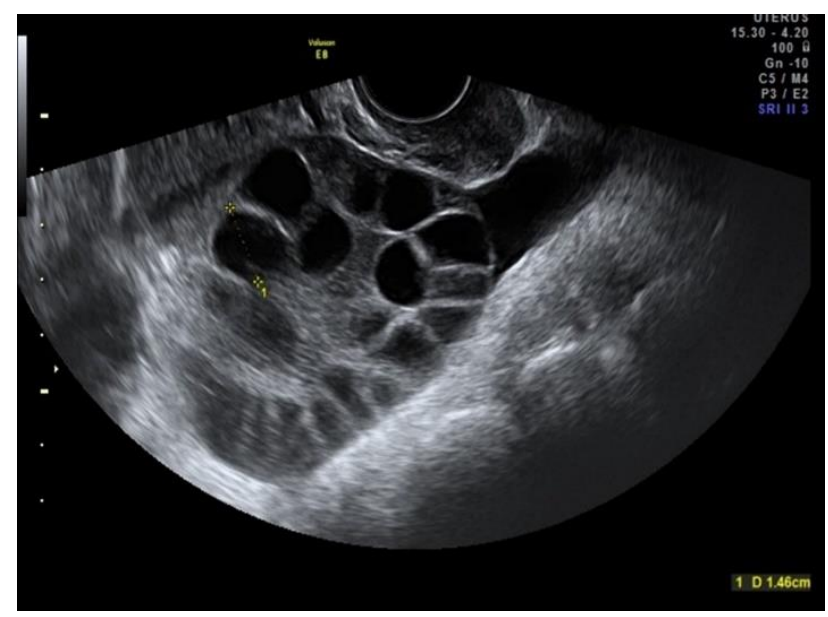

Figure 1: Stimulated ovary with multiple follicles.

Injection hCG 10,000 IU was administered intra muscularly followed by ovum pick up after 36 hours in which 26 oocytes were retrieved. Injection leuprolide acetate depot $3.6 \mathrm{mg}$ was administered intramuscularly following oocyte retrieval and tablet cabergoline $0.5 \mathrm{mg}$ daily was advised for 8 days to prevent OHSS. Her oocytes were fertilized and embryos were cryopreserved. She was admitted for observation. On day-2 of admission, she complained of abdominal pain. On examination, her abdomen was soft and abdominal girth was $89 \mathrm{~cm}$ with stable vital parameters and adequate urine output. Ultrasonography (USG) was showing bilateral enlarged stimulated ovaries with mild free fluid in pelvis or abdomen. Over the next few days, she became progressively symptomatic with increasing abdominal pain, bloating sensation, abdominal distension, constipation, nausea and vomiting.

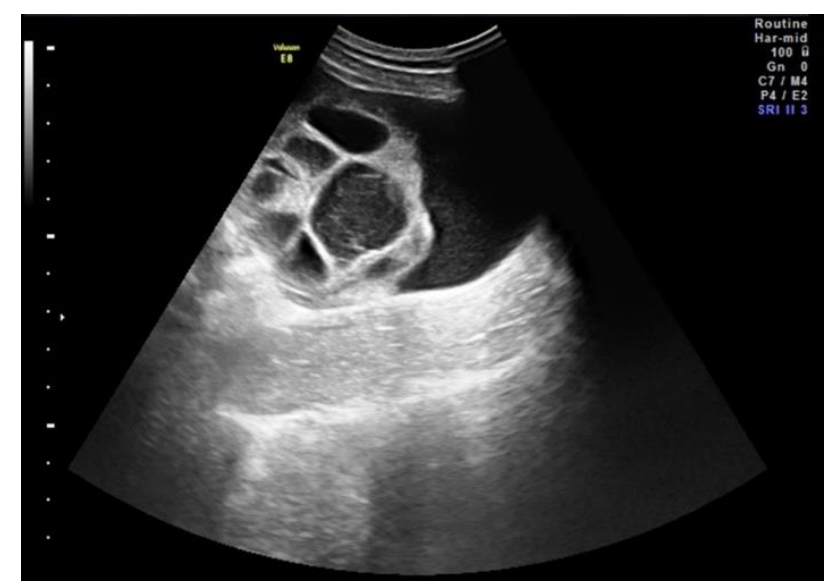

Figure 2: Enlarged ovary with free fluid in pelvis
Her abdominal girth increased from $89 \mathrm{~cm}$ to $99 \mathrm{~cm}$ within 5 days with USG showing free fluid in POD and moderate ascites (Figure 2 and 3 ).

She was managed conservatively with crystalloids, intravenous albumin 20\% (100 cc) 12 hourly infusion, monitoring of vital parameters and input output charting. In the following days, she developed tense ascites with bilateral lower limb edema which progressed to generalized swelling all over the body. Injection Low molecular weight heparin (LMWH) was started to prevent thrombotic complications.

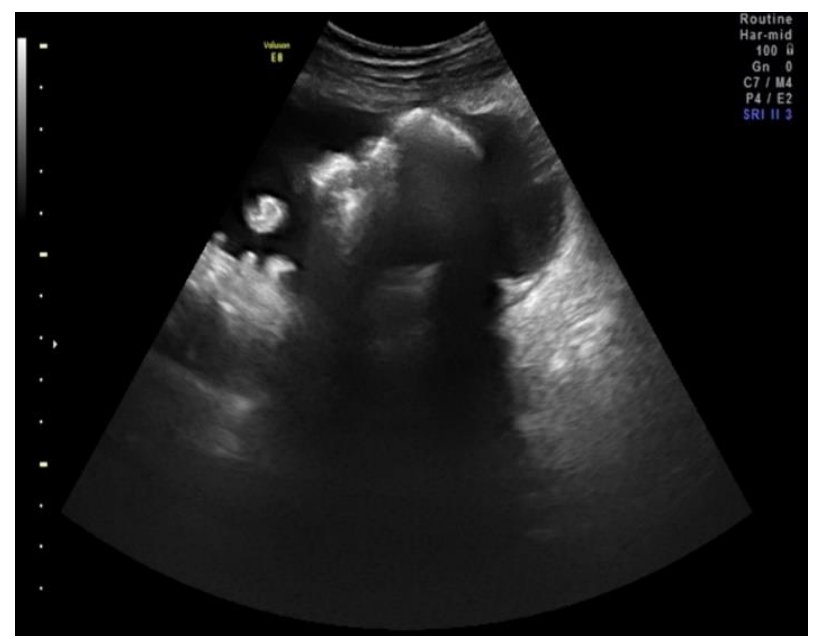

Figure 3: Gross ascites

Color Doppler study of lower limbs was normal with USG showing lymphatic dilatation in bilateral lower limbs. She developed progressive dyspnea and oliguria. Her USG thorax was normal with no evidence of pleural effusion. Although hemodynamic improvement started, oliguria persisted with tense ascites and abdominal girth of $110 \mathrm{~cm}$. Her clinical and laboratory parameters are shown in Table 1.

Decision of therapeutic paracentesis was taken to relieve compression of inferior vena cava and renal veins. Paracentesis was done and 1.5 litres of ascitic fluid drained out. Her urine output increased over the next 2 days but she developed dyspnea with cough and pink frothy sputum. On auscultation, there were bilateral inspiratory crackles and expiratory wheeze with diminished air entry. Supportive therapy with fluid restriction, diuretics (frusemide), intravenous antibiotics and nebulisation were started. She became symptomatically better over next 5 days with decreasing abdominal distension, disappearance of respiratory symptoms and no evidence of ascites on USG. She was discharged after 19 days of admission. On follow up after 10 days, she was asymptomatic with normal USG findings. 
Table 1: Clinical and laboratory parameters.

\begin{tabular}{|c|c|c|c|c|c|c|c|c|c|}
\hline & Day 1 & Day 3 & Day 5 & Day 7 & Day 9 & Day 11 & Day 13 & Day 16 & Day 19 \\
\hline $\begin{array}{l}\text { Abdominal } \\
\text { girth }(\mathrm{cm})\end{array}$ & 89 & 95 & 99 & 106 & 110 & 107 & 102 & 99 & 92 \\
\hline $\mathrm{Hb}(\mathrm{g} / \mathrm{dl})$ & 11.5 & 15.3 & 13.2 & 10.3 & 8.3 & 8.1 & 8.5 & 8.4 & 9.2 \\
\hline PCV $(\%)$ & 35 & 47.6 & 40 & 31.9 & 24.5 & 25.3 & 26.6 & 26.4 & 30 \\
\hline $\begin{array}{l}\text { Total proteins } \\
(\mathrm{mg} / \mathrm{dl})\end{array}$ & 5.0 & 5.1 & 4.0 & 4.9 & 5.8 & 6.3 & 6.1 & 6.0 & 6.2 \\
\hline $\begin{array}{l}\text { S. Albumin } \\
\text { (mg/dl) }\end{array}$ & 2.0 & 2.2 & 1.9 & 2.1 & 3.7 & 4.0 & 3.7 & 3.6 & 3.7 \\
\hline $\begin{array}{l}\text { S. Creatinine } \\
(\mathrm{mg} / \mathrm{dl})\end{array}$ & 0.76 & 0.89 & 1.07 & 0.94 & 0.7 & 0.6 & 0.74 & 0.62 & 0.68 \\
\hline $\mathrm{Na} / \mathrm{K}(\mathrm{mEq} / \mathrm{l})$ & $132 / 4.1$ & $133 / 5.3$ & $130 / 4.4$ & $131 / 4.0$ & $134 / 4.2$ & $138 / 4.1$ & $140 / 3.8$ & $141 / 4$ & $136 / 3.8$ \\
\hline $\begin{array}{l}\text { USG } \\
\text { Abdomen }\end{array}$ & $\begin{array}{l}\text { Stimulated } \\
\text { Ovaries. } \\
\text { No ascites }\end{array}$ & $\begin{array}{l}\text { Free } \\
\text { fluid in } \\
\text { POD }\end{array}$ & $\begin{array}{l}\text { Moderate } \\
\text { ascites }\end{array}$ & $\begin{array}{l}\text { Severe } \\
\text { ascites }\end{array}$ & $\begin{array}{l}\text { Severe } \\
\text { ascites }\end{array}$ & & & & $\begin{array}{l}\text { No } \\
\text { ascites }\end{array}$ \\
\hline USG Thorax & Normal & Normal & Normal & & Normal & & & & Normal \\
\hline
\end{tabular}

\section{DISCUSSION}

Young women with PCOS have a higher incidence of OHSS after gonadotropin therapy than women with other causes of anovulatory infertility. OHSS is a self-limiting disorder but requires hospitalization in severe cases. Diuretics should be avoided in the initial phases of hemoconcentration as they may cause further intravascular volume depletion but may be used with careful hemodynamic monitoring if oliguria persists, despite intravascular volume expansion. Paracentesis should be considered in patients with significant discomfort due to marked ascites or when oliguria persists despite adequate volume expansion. Thromboprophylaxis may be administered in all patients with severe OHSS. Intravenous albumin should be administered only when hypo-albuminemia is proven because of risk of hepatitis, excessive albumin overload, renal function impairment, potential viral contamination, potential for worsening OHSS, and the risk of pulmonary edema in patients with diminished cardiac reserve6. Possible causes of dyspnea are ascites and rare manifestations of OHSS such as pleural effusion, pulmonary edema, atelectasis, pulmonary embolism, ARDS and pericardial effusion. ${ }^{7}$ Pulmonary edema, a rare but fatal complication of OHSS is thought to be due to increased capillary permeability. Strict fluid management and diuresis may prevent serious respiratory sequelae in these patients. In our case, pulmonary edema occurred in the last few days of treatment when patient was improving hemodynamically. From the outset of treatment, our patient, who had severe dyspnea, ascites and edema in both legs and back, low molecular heparin was administered as a preventive measure for deep vein thrombosis and protection against possibility of pulmonary embolism. As patient had difficulty in breathing and bilateral severe pedal edema, paracentesis was performed after which patient started improving.
Urine output improved, edema reduced and patient became symptomatically better. But then, she developed pulmonary edema which was treated with fluid restriction and diuretics. The cause of pulmonary edema during recovery phase is an increase in intravascular volume due to shifting of fluid from extravascular to intravascular compartment. In patients of OHSS, pulmonary complications should be suspected on clinical grounds and identified early to allow for appropriate diagnosis and management.

\section{CONCLUSION}

The risk of OHSS can be reduced by proper patient selection, individualizing stimulation protocols, cautious use of medications and by withholding hCG. Patients with OHSS must be treated urgently and with multidisciplinary management.

Funding: No funding sources

Conflict of interest: None declared

Ethical approval: Not required

\section{REFERENCES}

1. Madill JJ, Mullen NB, Harrison BP. Ovarian hyperstimulation syndrome: A potentially fatal complication of early pregnancy. J Emerg Med. 2008;35(3):283-6.

2. Binder H, Dittrich R, Einhaus F, Krieg J, Muller A, Strauss R. Update on ovarian hyperstimulation syndrome: Incidence and pathogenesis. Int J Fertil Womens Med. 2007;52:11-26.

3. Selgas R, Del Peso G, Bajo MA. Intra-abdominal hypertension favors ascites. Perit Dial Int. 2010;30:156-7.

4. Chen SU, Chen RJ, Shieh JY, Chou CH, Lin CW, Lu H. Human chorionic gonadotropin up-regulates 
expression of myeloid cell leukemia-1 protein in human granulosa-lutein cells: implication of corpus luteum rescue and ovarian hyperstimulation syndrome. J Clin Endocrinol Metab. 2010;95:3982-92.

5. Hammam AS. Pulmonary edema complicating ovarian hyperstimulation syndrome: Low pressure edema, high pressure edema, or mixed edema? Ann Saudi Med. 2005;25:335-8.

6. Ben-Chetrit A, Eldar-Geva T, Gal M, Huerta M, Mimon T, Algur N. The questionable use of albumin for the prevention of ovarian hyperstimulation syndrome in an IVF programme: A randomized placebo-controlled trial. Hum Reprod. 2001;16:1880-4.

7. Abramov Y, Elchalal U, Schenker JG. Pulmonary manifestations of severe ovarian hyperstimulation syndrome: A multicenter study. Fertil Steril. 1999; $71: 645-51$

Cite this article as: Mishra V, Roy P, Choudhary S, Aggarwal R, Hokabaj S, Saini SR. Ovarian hyperstimulation syndrome and pulmonary edema a rare complication. Int J Reprod Contracept Obstet Gynecol 2017;6:1154-7. 